\title{
Morphology and morphometric relationships for sagitta otoliths in Lutjanus argentiventris (Pisces: Lutjanidae) and Hyporthodus acanthistius (Pisces: Serranidae) from the Colombian Pacific Ocean
}

\author{
Vladimir Puentes ${ }^{1, *}$, Paola Rojas ${ }^{2}$, Giovanni Pavolini ${ }^{3}$, Carlos F. Gutiérrez ${ }^{4}$, Ángel A. Villa ${ }^{5}$
}

Edited by

Juan Carlos Salcedo-Reyes

(salcedo.juan@javeriana.edu.co)

1. Fundación Amano, Bogotá D.C.,

Colombia.

2. Parques Nacionales Naturales de

Colombia. Cali, Colombia.

3. Pavolini \& Co. Cali, Colombia.

4. Universidad del Valle, Cali, Colombia.

5. Unidad de Planificación Rural

Agropecuaria - UPRA, Bogotá D.C.,

Colombia.

*zanclus0715@gmail.com

Received: 16-04-2018

Accepted: 05-03-2019

Published on line: 29-05-2019

Citation: Puentes V, Rojas P, Pavolini G, Gutiérrez CF, Villa AA. Morphology and morphometric relationships for sagitta otoliths in Lutjanus argentiventris (Pisces: Lutjanidae) and Hyporthodus acantbistius

(Pisces: Serranidae) from the Colombian Pacific Ocean, Universitas Scientiarum, 24 (2): 337-361, 2019.

doi: 10.11144/Javeriana.SC24-2.mamr

Funding:

N.A.

Electronic supplementary material: N.A.

OPEN ACCESS

\section{Abstract}

Fish earstones, or otoliths, are inner ear structures that can be studied to determine a fish's age and are a source of taxonomically informative data. In the present work, sagitta otoliths of the Yellowtail snapper (Lutjanus argentiventris) and the Red grouper (Hyporthodus acanthistius) were collected in the Colombian Pacific, and their key morphological features were studied. Otoliths of the Yellowtail snapper were distinctly concave by their distal surface, revealing features shared with species of its genus (Lutjanus). Red grouper otoliths were elliptic and compressed laterally by their proximal surface, bearing similarities to those of other Serranid species. Morphometric relationships between otolith size weight and whole fish size and weight were also studied. In Red groupers significant statistical morphometric relationships between otolith and body features were found via power regression models; successfully relating otolith length with total fish length, otolith weight with total fish length, otolith length with total fish weight, and otolith weight with total fish weight. No significant morphometric relationships were found for the Yellow snapper data. In both fish species, otolith transversal sections proved best to identify its internal features and to distinguish otolith growth rings, as a method for determining the specimen's age.

Keywords: Colombian Pacific Ocean; Hyporthodus acanthistius; Lutjanus argentiventris; otoliths.

\section{Introduction}

Otoliths or "earstones" are small, white structures found in the head of all bony fishes. Otoliths provide balance and aid in hearing (Campana, 2004). Otoliths are also helpful to understanding different fish features and are taxonomically informative. These structures have been central in fish paleontological research (Smale et al., 1995; Nolf, 1995), taxonomical studies (Martínez \& Monasterio 
de Gonzo, 1991), and in fish stock identification studies (Friedland \& Reddin, 1994; Farias et al., 2009).

Among the three otolith types distinguished in the internal fish ear (namely, the asteriscus, lapillus and sagitta), sagitta otoliths exhibit the largest interspecific morphological variation (Popper \& Coombs, 1982; Williams \& McEldowney, 1990; Martínez \& Monasterio de Gonzo, 1991; Smale et al., 1995) and have been studied to identify ontogenic changes in growth, sexual dimorphism, or morphometric relationships in different fish species (Colura \& King 1995; Tuset et al., 2003; Yamauchi et al., 2008; Carvalho \& Corrêa, 2014). Because otoliths grow at a steady rate, their sectioning and growth ring count constitute the handiest and most reliable way to determine a fish's age (Puentes et al., 2004; Green et al., 2009).

Otolith studies are scarce in tropical fishes since many local researchers have long argued that otolith analyses are expensive and useless. However, otolith utility was already demonstrated by Gjøsaeter et al., (1984) and MoralesNin, (1989) with their studies conducted in warm waters. In addition, age determination and growth studies employing otoliths in tropical fishes have shown good results in fish such as snappers (Morales-Nin \& Ralston, 1990; Claro et al., 1999; Newman, 2002) and groupers (Sadovy et al., 1992; Tuset et al., 2003; Reñones et al., 2007). Currently, otoliths are regarded as a useful tool to study the growth and age of Colombian ichthyofauna.

The Yellowtail snapper (Lutjanus argentiventris, Peters, 1869) is an economically important species in the Eastern tropical Pacific. This species inhabits waters off the coast from South California (USA) to Peru (Robertson \& Allen, 2006). In the Colombian Pacific, the Yellowtail snapper is commonly found in rocky bottoms at depths between $3 \mathrm{~m}$ and $119 \mathrm{~m}$ (Rojas \& Zapata, 2006). Its Average size at capture (Lt: Total Length), through artisanal longline fishing, ranges from $20 \mathrm{~cm}$ to $70 \mathrm{~cm}$, and its average size at maturity (L50) is $52 \mathrm{~cm} \mathrm{Lt}$. The Yellowtail snapper's reproductive season is between July and September (Rojas et al., 2004b).

Another economically relevant fish species in the tropical pacific is the Red grouper (Hyporthodus acanthistius, Gilbert, 1892). The Red grouper co-occurs with the Yellowtail snapper along its entire distribution range. The Red grouper inhabits rocky reefs and sandy bottoms (Robertson \& Allen, 2006) and can be found between depths of $18 \mathrm{~m}$ and $119 \mathrm{~m}$ in the Colombian Pacific (Rojas \& Zapata, 2006). The Red grouper's capture size (artisanal longline) is between $24 \mathrm{~cm}$ and $85.5 \mathrm{~cm} \mathrm{Lt}$, with an average capture size of $51 \mathrm{~cm} \mathrm{Lt}$, which is the lowest average capture size reported since 1998 in the Colombian Pacific Ocean (Barreto \& Borda, 2008). The Red grouper's average size at maturity 
(L50) is $63.5 \mathrm{~cm} \mathrm{Lt}$, and several reproductive peaks have been recorded in the second half of the year (Rojas et al., 2004a).

Four studies have been published in Colombia using bony structures, such as pectoral spines (Reina et al., 1995), urohial bones (Arévalo et al., 2004), lapillus otoliths (Zapata \& Herrón, 2002) and vertebra (Mejía-Falla et al., 2014). In the present study we aimed at describing the morphology of whole sagitta otoliths of Yellowtail snapper and Red groupers caught in the Colombian Pacific, studying otolith sections for fish age determination, and analyzing different otolith-fish body morphometric relationships.

\section{Materials and methods}

Fish specimens and whole sagitta otolith analyses

Yellowtail snapper and Red grouper specimens were collected from the experimental small-scale long line fishery of the National Natural Park Gorgona $\left(78^{\circ} 09-78^{\circ} 14 \mathrm{~W}-2^{\circ} 56-2^{\circ} 59 \mathrm{~N}\right)$; the sampling area, where fishing was interdicted, was established for the park's fish monitoring program. Sampling also was conducted in the park's neighboring areas, located off the Colombian Pacific coast (Fig. 1). For each Yellowtail snapper specimen L. argentiventris $(\mathrm{n}=58)$ and Red grouper specimen H. acanthistius $(\mathrm{n}=109)$, sex, maturity stage, total length (Lt), and total weight (Wt) were recorded. Sagitta otoliths were extracted from each specimen, and the features of the whole left sagitta otolith were examined under a LEICA MZ12.5 stereoscope (Leica Microsystems, Heerbrugg, Switzerland). This analysis consisted on describing different otolith structures illustrated in Fig. 2A and as follows.

Along an otolith's anterior-posterior axis, in the middle area, lies a structure called the sulcus acusticus. The sulcus is usually divided into two sections, one anterior and the other posterior: the ostium and the cauda, respectively. Both ostium and cauda are lined by the crista, a rim developed and evident; the crista has a frequently raised floor, the collicullum. The sulcus acusticus of each otolith was described considering the relationship between its ostium and cauda, the type of the opening, and its position on the otolith. The ostium generally reaches the anterior margin of the otolith where it opens onto the excisura ostii. The rostrum is a protuberance in the anterior margin of the otolith, ventral to the opening of the ostium; the antirostrum is a protuberance that is normally smaller than the rostrum and sometimes develops dorsal to the opening of the ostium, where the excisura ostii forms a notch. In the present otolith description, the shapes of both the rostrum and the antirostrum were described as peaked, round, or blunt. The cauda, 

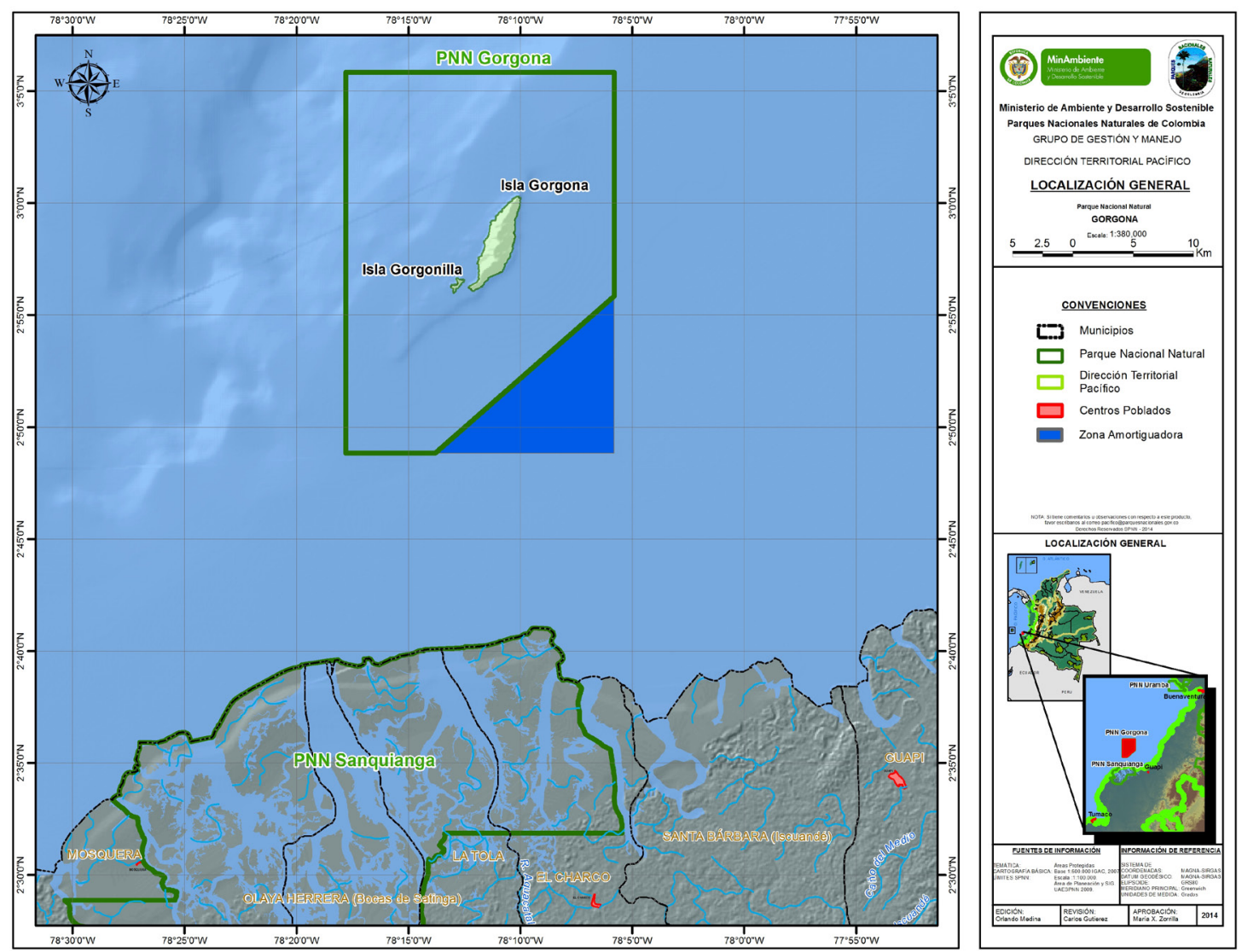

Figure 1. Location of Parque Nacional Natural Gorgona, off the Colombian Pacific coast, and its neighboring area. This map was provided by Sistema de Parques Nacionales Naturales de Colombia, Dirección Territorial Pacífico, Sistemas de Información Geográfica. 2014.

at the posterior margin of the otolith, is most frequently closed and often exhibits a ventrally curved tip that does not reach the posterior margin of the otolith; determining the shape and type of the cauda was part of the present otolith description. The margins are the outlines of the otolith, and for this study, the following cauda shapes were considered: a) Sinuate: margin finely sinuous and regular; b) Crenate: margin regularly wavy, forming round and superficial crenulations; c) Dentate: round tipped margin and with fused projections, occasionally separated by very narrow and shallow indentations; d) Serrate: margin with small sharp regular tips; and e) Irregular: margin with irregularly spaced slots and protuberances. 
A

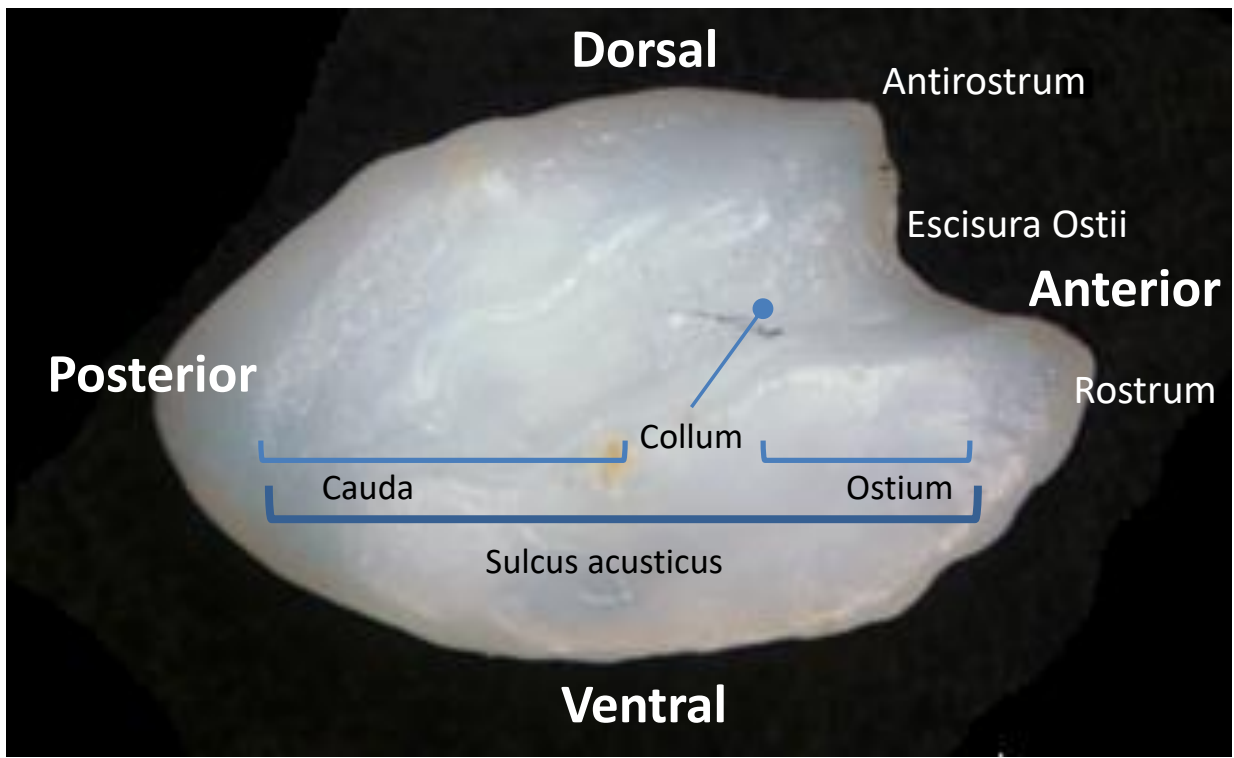

B

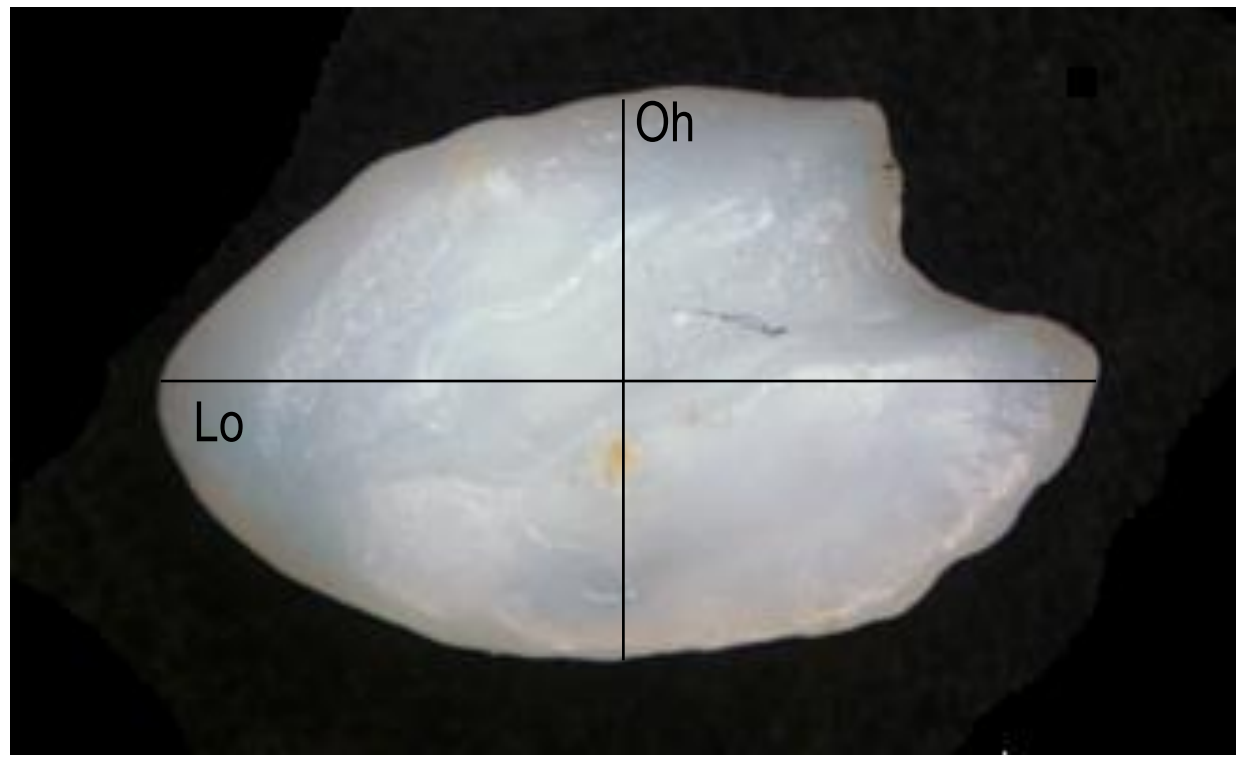

Figure 2. View of the proximal surface of a Sagitta otolith. A) Most relevant characteristics of the proximal surface; B) Otolith Length (Lo) and Otolith width (Oh).

The whole left sagitta otolith of each specimen was removed and studied following Tuset et al., (2008). The length of each left otolith was measured to the nearest $0.1 \mathrm{~mm}$ (Fig. 2B) and its weight recorded with a precision of $0.001 \mathrm{~g}$. These otolith data were used to calculate the following relationships: Total Length $(\mathrm{Lt})$ as a function of Otolith Length $(\mathrm{Ol})$, Total length $(\mathrm{Lt})$ as a function of Otolith weight $(\mathrm{Ow})$, Total Weight $(\mathrm{Wt})$ as a function of Otolith weight $(\mathrm{Ow})$, and Total Weight $(\mathrm{Wt})$ as a function of Otolith length $(\mathrm{Ol})$. Three different models (linear, power, and exponential) were fit to the cloud of measurements. These analyses were done for each species separately, taking sex into account as a covariable. Model fit of the data was evaluated based on 
the following metrics: significance $(\mathrm{p}<0.05)$, coefficient of determination $\left(\mathrm{r}^{2}\right)$, and Akaike's Information Criterion (AIC). The model with the lowest AIC value was retained as the model with the minimal variables necessary to explain the morphometric relationship. Data for morphometric relationships were analyzed using R (R Core Team, 2018) as implemented in RStudio (Studio Team, 2016). The package data.table (Dowle \& Srinivasan, 2018) was employed to handle datasets and plots were generated with packages ggplot2 (Wickham, 2016) and gridExtra (Auguié, 2017).

\section{Otolith section analyses}

Left sagitta otoliths of $37 \mathrm{~L}$. argentiventris and $61 \mathrm{H}$. acanthistius specimens were sectioned. Prior to sectioning, each otolith was embedded in epoxy resin for 48 hours. Once compacted and labeled, each resin-embedded otolith was subjected to longitudinal and transversal sections made through its nucleus with a Microcutter type MC-201 (Maruto Co. Ltd. Tokyo, Japan) and polished with a polisher type 9820 (Makita Co., Ltd, Tokyo, Japan). This resulted in $0.2 \mathrm{~mm}$ otolith sections; each section was mounted on a labeled glass slide and was observed under a LEICA MZ12.5 stereoscope (Leica Microsystems, Heerbrugg, Switzerland). Since both longitudinal and transversal sections were mounted, these two were compared to identifying which was the best to describe otolith section morphology and to count and measure growth rings (Fig. 3).

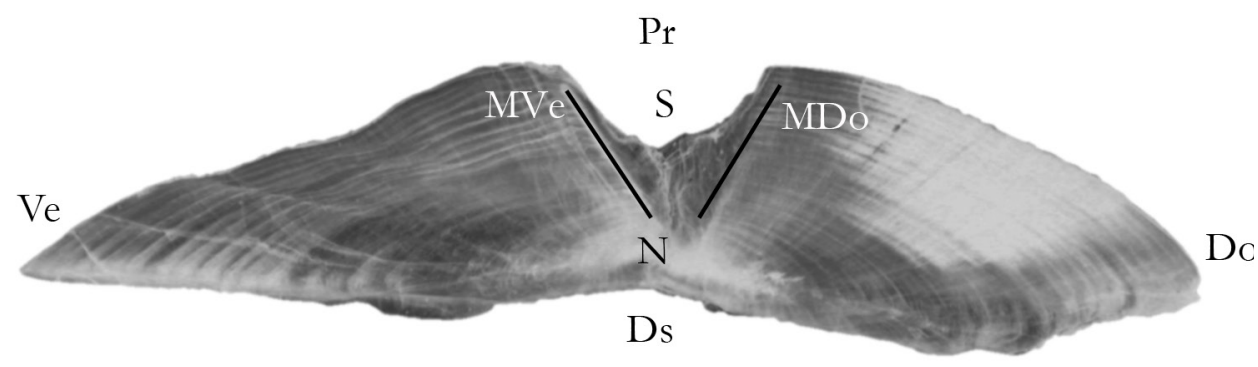

Figure 3. Transversal section of a sagitta otolith. Dorsal side (Do); Ventral side (Ve); Sulcus acusticus (S); Proximal surface (Pr); Distal surface (Ds); Nucleus $(\mathrm{N})$; Dorsal tip of the sulcus acusticus (MDo); and Ventral tip of the sulcus acusticus (MVe). 


\section{Results}

Relationship between body and otolith features in yellowtail snappers

The total length of Yellowtail snapper specimens ranged from $29 \mathrm{~cm}$ to $70 \mathrm{~cm}$ (mean length was $49.66 \mathrm{~cm}$ ) and their total weight ranged from $150 \mathrm{~g}$ to $4500 \mathrm{~g}$ (mean weight was $1693 \mathrm{~g}$ ). We observed no sexual dimorphism for these two traits among the specimens measured. The external morphology observations of Yellowtail snapper otoliths revealed that their texture is smooth in large fishes, whereas otoliths of small fishes are rough. Regardless of fish size, from a distal perspective, otoliths were sharply concave, and from a proximal perspective, otoliths appeared laterally compressed and elliptic. At the anterior side of the distal surface, rings forming around the nucleus could be distinguished by the naked eye. Otolith margins were slightly crenate. The sulcus acusticus was heterosulcoid, having an ostial opening at the median position, with well-developed dorsal and ventral cristae; the dorsal crista started at the antirostrum and connected with the ventral crista at the cauda, which is less prominent after the collum and towards the rostrum. The depth of the sulcus acusticus increased with otolith size. The caudae were tubular, curved, and markedly flexed from the middle region, ending close to the posterior margin. Each ostium was funnel-like and slightly longer than the cauda. The rostrae were short, broad and pointed whereas the antirostrae were underdeveloped or very small. The excisura ostii appeared wide and could be found either with or without a notch. The otolith's posterior region was oblique (Fig. 4A).

The relationships between otolith length or weight and fish length or weight were best described by fitting a power model to the data, as revealed in Table 1 and further described in Fig. 5. Neither exponential nor linear models were appropriate to explain the relationships between variables $(p>0.05)$. None of these models included sex a co-variable.

In our Yellowtail snapper otolith section analysis, we observed that transversal sections of were better than longitudinal ones at revealing internal otolith structures. Otolith section structures could be seen with direct or reflected light, but reflected light proved better (Fig. 4B). In all sections, the nuclei were well defined towards the distal surface and sulci acusticus gradually opened from the nucleus to the proximal surface in a "V" shape. The first two translucent zones of growth rings were wider and less defined than the subsequent ones. The best area to count and measure growth rings was located on, or slightly aside, the dorsal tip of the sulcus acusticus. Observed growth rings ranged from 2 (female specimen, $32 \mathrm{~cm}$ total length, $26 \mathrm{~cm}$ standard length, $920 \mathrm{~g}$ total weight) to 17 (male specimen, total length of $60 \mathrm{~cm}$, standard 
Table 1. Best model fitting of Yellowtail snapper length and weight as functions of otolith length and weight. Table caption: $\mathrm{Lt}=$ Total length, $\mathrm{Wt}=$ Total weight, $\mathrm{Ol}=$ Otolith length, $\mathrm{Ow}=$ Otolith weight. The equations with the best fit (power model) and their respective residual plots are shown in Fig. 5.

\begin{tabular}{ccccc}
\hline Regression formula & Model & $\mathbf{r}^{2}$ & $\mathbf{p}$ & AIC \\
\hline$L_{t}=2.87 * O_{l}{ }^{1.11}$ & power & 0.524 & $\mathrm{p}<0.05$ & 49.927 \\
$L_{t}=75.9 * O_{w}{ }^{0.26}$ & power & 0.331 & $\mathrm{p}<0.05$ & 34.152 \\
$W_{t}=0.127 * O_{l}{ }^{3.66}$ & power & 0.573 & $\mathrm{p}<0.05$ & 53.016 \\
$W_{t}=5617 * O_{w}{ }^{0.78}$ & power & 0.397 & $\mathrm{p}<0.05$ & 32.666 \\
\hline
\end{tabular}

length of $50 \mathrm{~cm}$, total weight of $4500 \mathrm{~g}$ ). However, we found a female specimen with a total length of $70 \mathrm{~cm}$ (standard length of $61 \mathrm{~cm}$, total weight of $5500 \mathrm{~g}$ ) with 16 growth rings. We also observed five otoliths with recently formed external growth rings (three in February one in March, and one in April).

\section{Relationship between body and otolith features in Red groupers}

Among the 109 studied Red grouper specimens, total length ranged from $27.5 \mathrm{~cm}$ to $75 \mathrm{~cm}$ (mean length was $51.7 \mathrm{~cm}$ ), and total weight ranged from $250 \mathrm{~g}$ to $5400 \mathrm{~g}$ (mean weight was $2196 \mathrm{~g}$ ). Regarding otolith morphology in this fish species, we observed that bigger otoliths were smooth and small ones were rough. From the proximal perspective, otoliths were laterally compressed and elliptic in appearance, being slightly concave from the distal surface. Margins were crenate. In each otolith the sulcus acusticus was heterosulcoid, with an ostial opening at the median position; the dorsal and ventral cristae were well developed, and the ventral cristae faded away around the ostium. In large otoliths, the collum appeared well developed and differentiated by both dorsal and ventral crista. The caudae were tubular, sinuously curved, and flexed from the middle region ending close to the posterior-ventral margin. Ostiae were funnel-like and shorter or slightly shorter than the cauda in larger otoliths. In each of the Red grouper otoliths, the rostrum was relatively long (1/4 of the otolith length), broad, and pointed with an underdeveloped antirostrum. The excisurae ostii were wide, without a notch, and exhibiting 
A

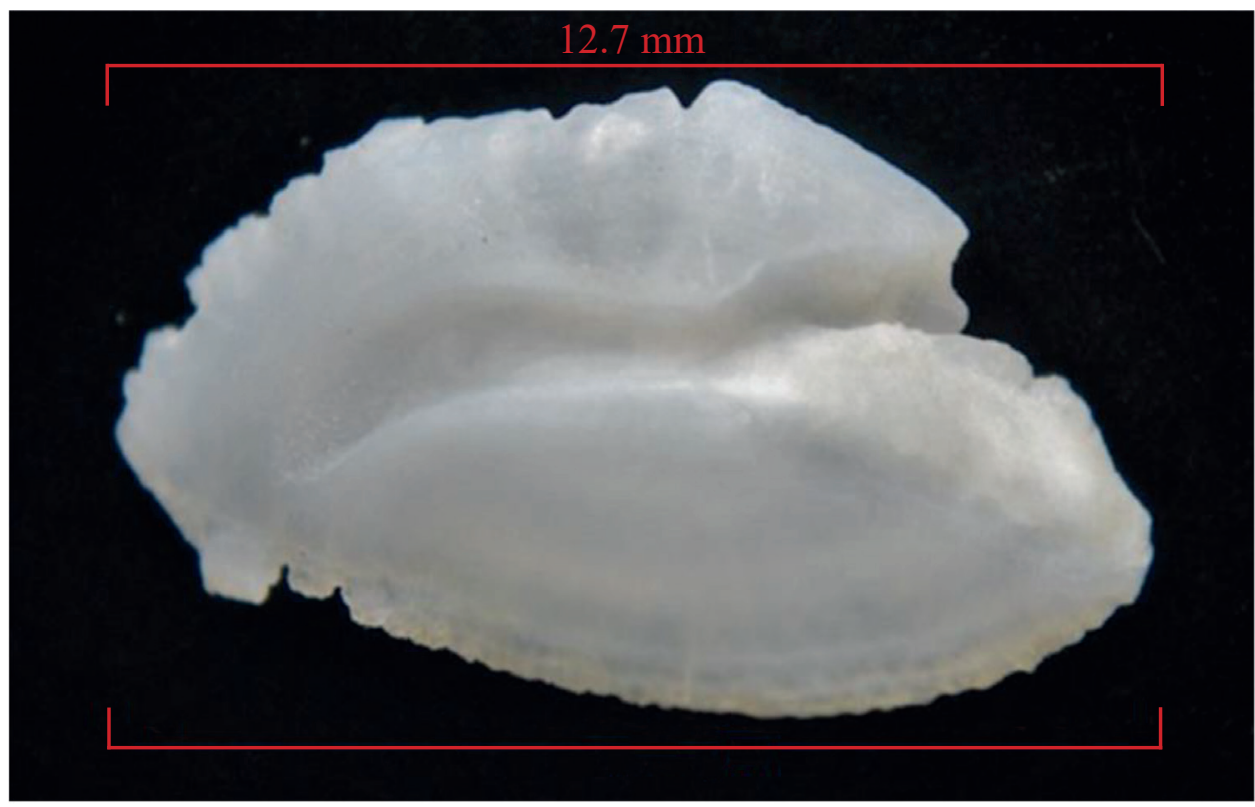

B

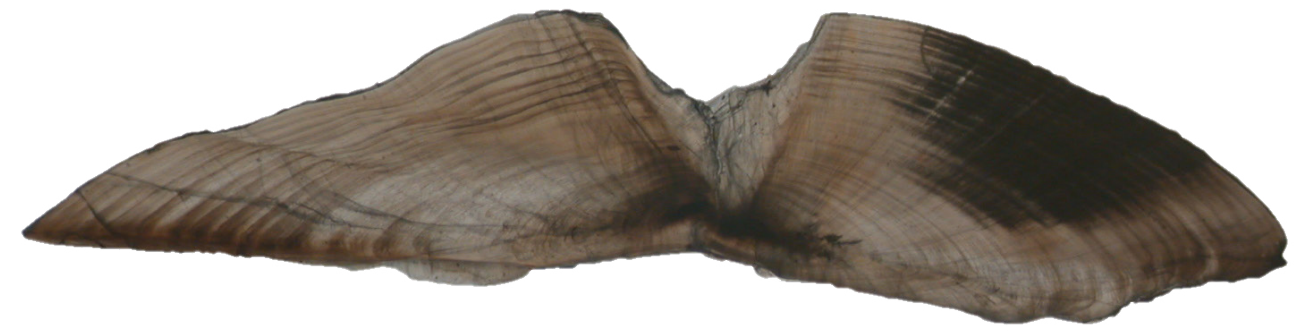

Figure 4. A) Left Sagitta otolith, observed under reflected light, of a Lutjanus argentiventris specimen of $52.6 \mathrm{~cm}$ (total length) and $1950 \mathrm{~g}$ (total weight); B) Transversal section of a sagitta otolith of a Lutjanus argentiventris specimen of $60 \mathrm{~cm}$ (total length) and $4500 \mathrm{~g}$ (total weight).

oblique posterior regions. All growth rings were observed with the naked eye in the middle of the distal surface. from the anterior part to the excisura ostii around the nucleus, showing some slots. Some otoliths had calcareous accretions, especially on the margins (Fig. 6A).

We studied Red grouper otolith internal features using transversal sections under reflected light (Fig. 6B). Otolith nuclei were well defined towards the distal surface; each otolith exhibited a sulcus acusticus opening gradually towards the proximal surface with its ventral tip more developed than the dorsal one. We counted and measured growth rings in each otolith section slightly next to the ventral tip of the sulcus acusticus. Among the set of red 
A
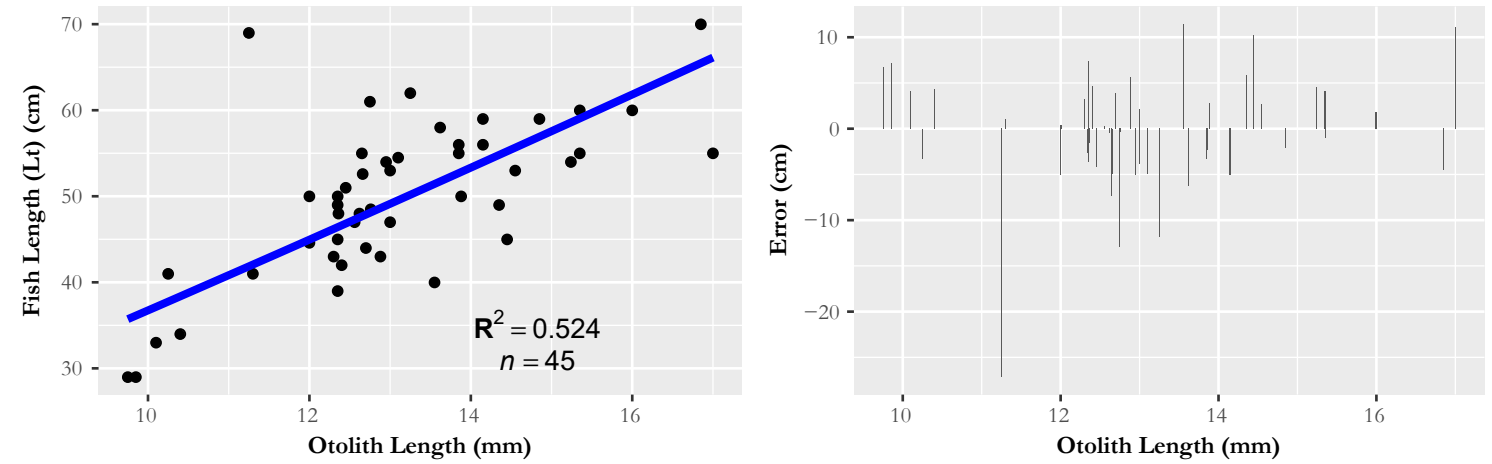

B
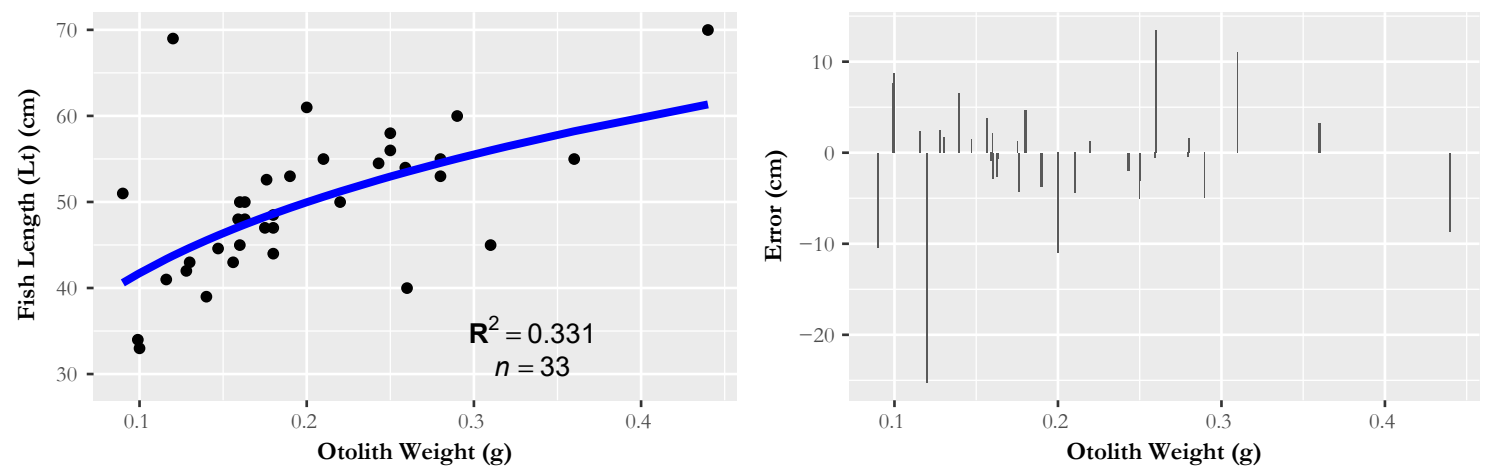

C
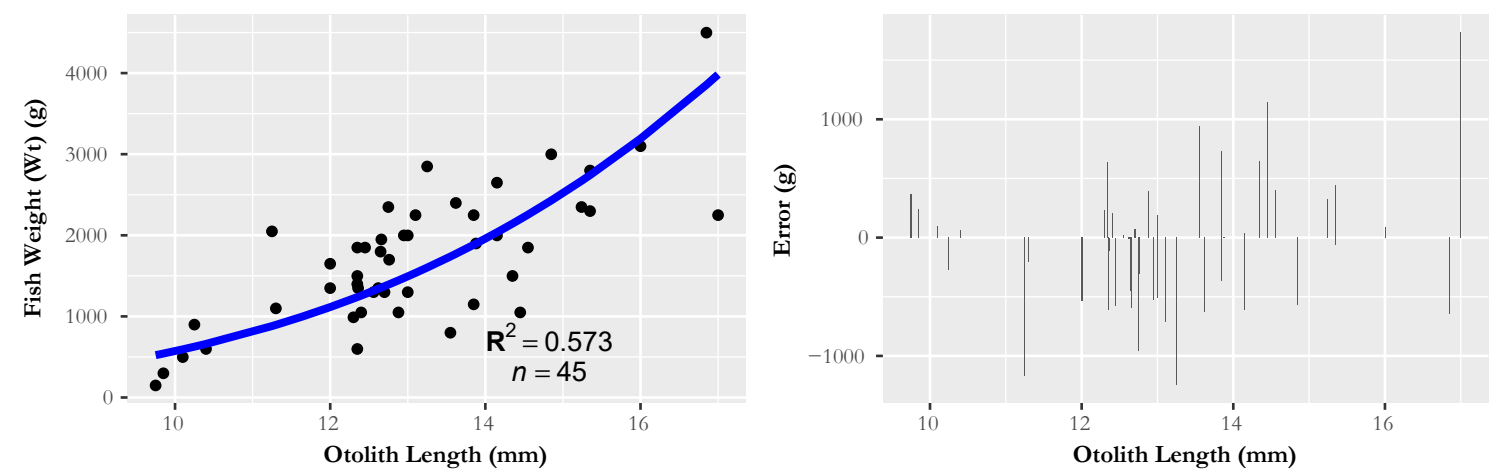

D
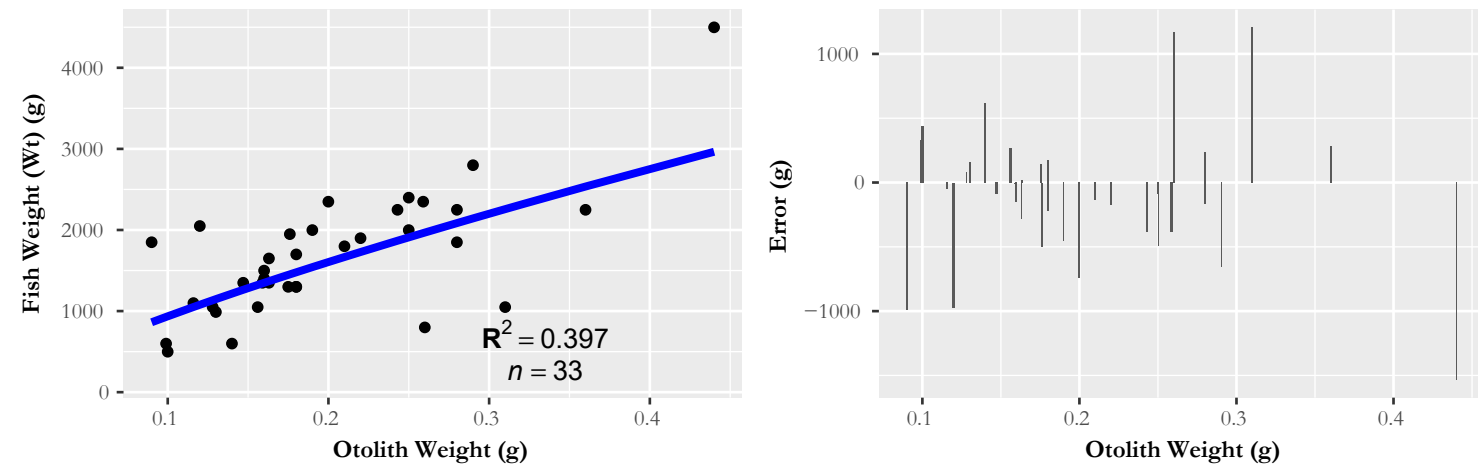

Figure 5. Power regressions between otolith length and weight data as explanatory variables for fish length and weight in the yellowtail snapper (Lutjanus argentiventris) alongside with their respective residual plots. A) otolith length vs. fish length; B) otolith weight vs. fish length; C) otolith length vs. fish weight; and D) otolith weight vs. fish weight. 


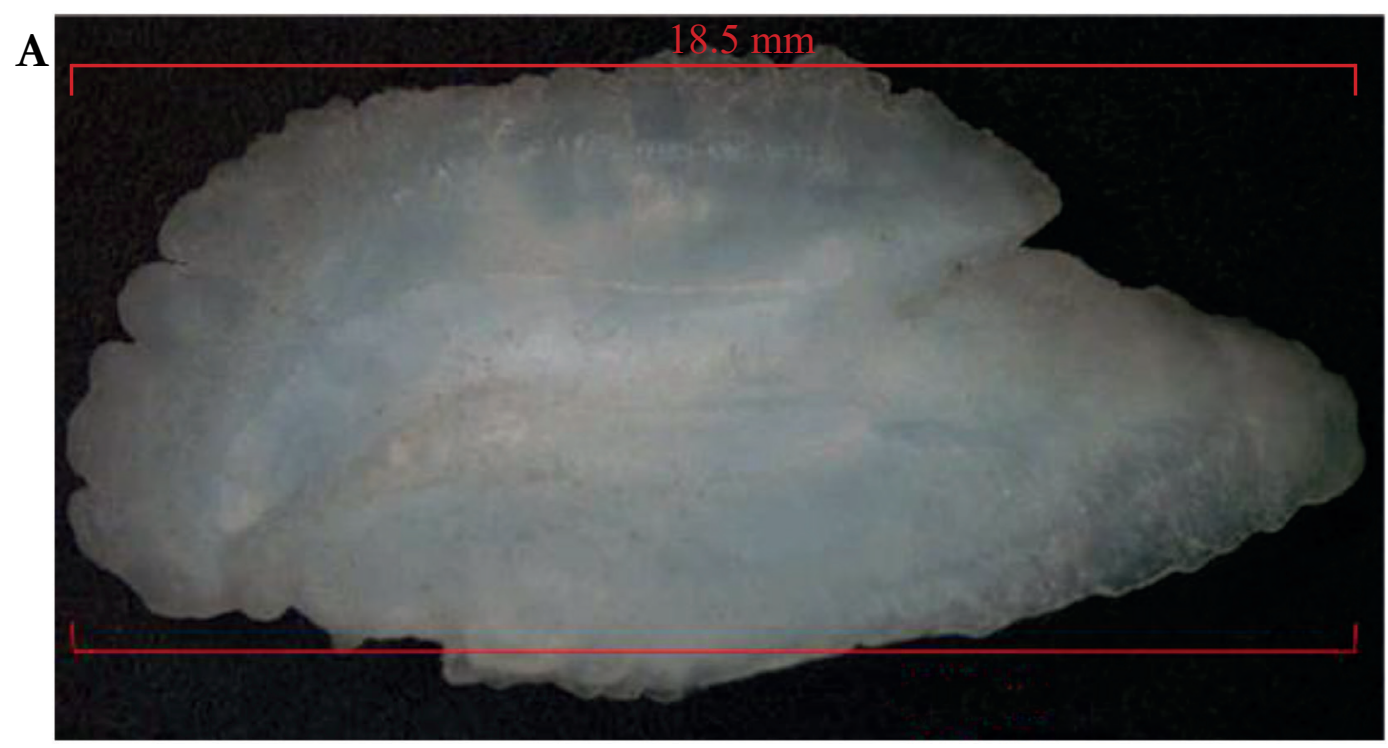

B

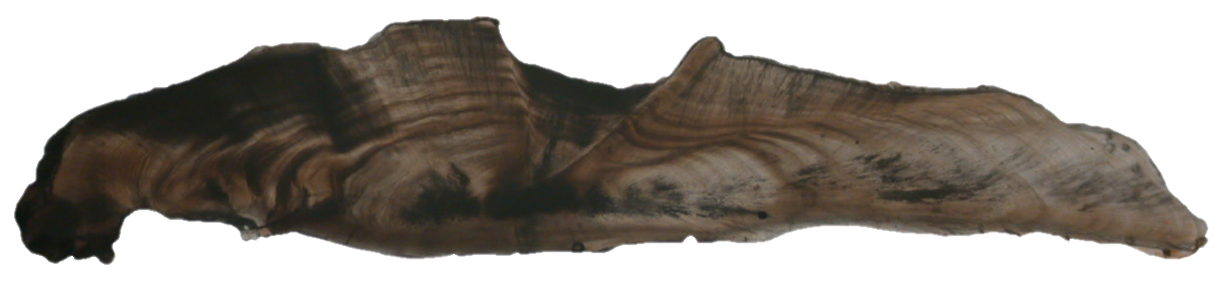

Figure 6. A) Left Sagitta otolith observed under reflected light of a Hyporthodus acanthistius specimen of $71 \mathrm{~cm}$ (total weight) and $5400 \mathrm{~g}$ (total weight); B) Transversal section of a sagitta otolith of Hyporthodus acanthistius, observed under reflected light.

grouper otoliths, the growth rings observed ranged from 2 (undetermined sex specimen with a total length of $63 \mathrm{~cm}$, standard length of $50 \mathrm{~cm}$ and total weight of $2900 \mathrm{~g}$ ) to 18 (two undetermined sex specimens, one with a total length of $75 \mathrm{~cm}$, standard length of $60 \mathrm{~cm}$ and total weight of $6000 \mathrm{~g}$, and the other with a total length of $72 \mathrm{~cm}$, standard length of $60 \mathrm{~cm}$ and total weight of $4850 \mathrm{~g}$ ). Recently formed growth rings were found in three otoliths (one in July and two in August).

The relationships between otolith length and weight and fish length and weight in Red groupers were best described by fitting power models to the data, as shown in Table 2 and further explained Fig. 7. Neither exponential nor linear models satisfactorily explained the relationships between variables $(\mathrm{p}>0.05)$. 
Table 2. Best model fitting of Red grouper length and weight as functions of otolith length and weight. Table caption: $\mathrm{Lt}=$ Total length, $\mathrm{Wt}=$ Total weight, $\mathrm{Ol}=$ Otolith length, $\mathrm{Ow}=$ Otolith weight. The equations the best fit (power model) and their respective residual plots are shown in Fig. 7.

\begin{tabular}{ccccc}
\hline Regression formula & Model & $\mathbf{r}^{2}$ & $\mathbf{p}$ & AIC \\
\hline$L_{t}=1.765 * O_{l}{ }^{1.24}$ & power & 0.880 & $\mathrm{p}<0.05$ & 174.597 \\
$L_{t}=97.611 * O_{w}{ }^{0.45}$ & power & 0.873 & $\mathrm{p}<0.05$ & 185.455 \\
$W_{t}=0.085 * O_{l}{ }^{3.66}$ & power & 0.819 & $\mathrm{p}<0.05$ & 45.545 \\
$W_{t}=13032 * O_{w}{ }^{1.34}$ & power & 0.831 & $\mathrm{p}<0.05$ & 44.536 \\
\hline
\end{tabular}

\section{Discussion}

We have conducted the first morphological study of whole sagitta otoliths and their transversal sections in yellowtail snapper and red grouper specimens from the Colombian Pacific Ocean. The observed Yellowtail snapper otoliths show similarity with otoliths of lutjanid species from Australia (Newman et al., 1996; Newman et al., 2000). These otoliths are also akin to the ones studied in other snapper species, Lutjanus lutjanus, from the Persian Gulf (Sadighzadeh et al., 2014). The most common characteristic for sagitta otoliths of the genus Lutjanus, is that they may be distinctly concave from their distal surface.

Transversal sections of Yellowtail snapper sagitta otoliths allowed us to identify growth rings. We counted a maximum of 17 growth rings, showing that age and growth estimations based on otolith analysis are possible for this species. Although, we did not validate the periodicity of growth rings in our Yellowtail snapper specimens, we rely on evidence from other studies of lutjanid tropical species demonstrating the annual growth of rings, for instance in Australian Lutjanus carponotatus, Lutjanus vitta and Lutjanus malabaricus (Newman et al., 1996; Newman et al., 2000), in Hawaiian Lutjanus kasmira (Morales-Nin \& Ralston, 1990), in North American Ocyurus chrysurus (Garcia et al., 2003), in Caribbean and Central American a Lutjanus jocu (Claro et al., 1999), Lutjanus synagris (Aiken, 2001), and Lutjanus. guttatus (Soto-Rojas et al., 2009). We are aware of the importance of validating absolute age and ring increment periodicity to gain accuracy with this fish aging tool. 
A
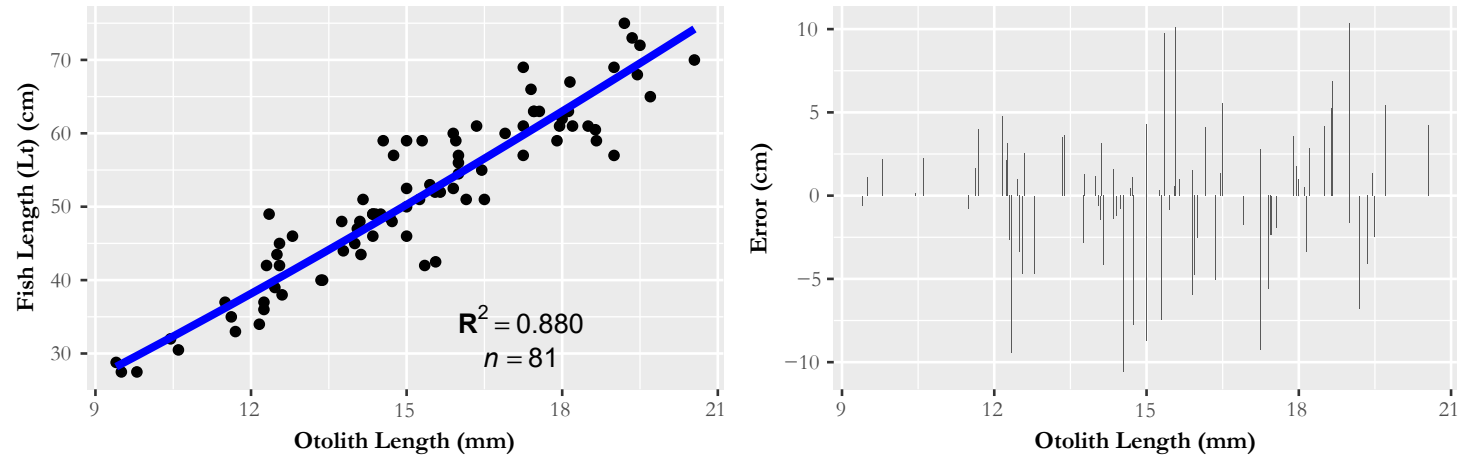

B

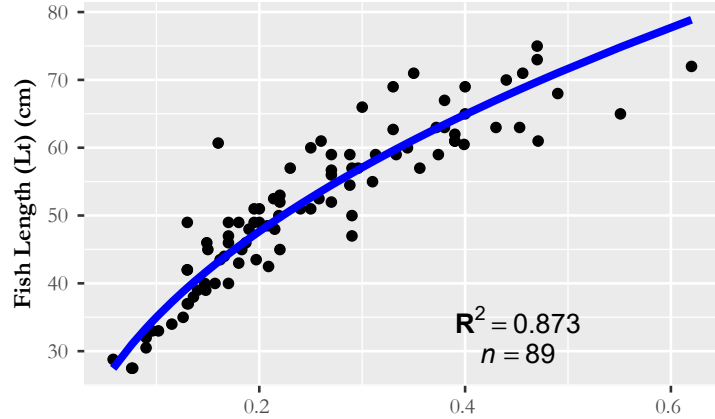

Otolith Weight (g)

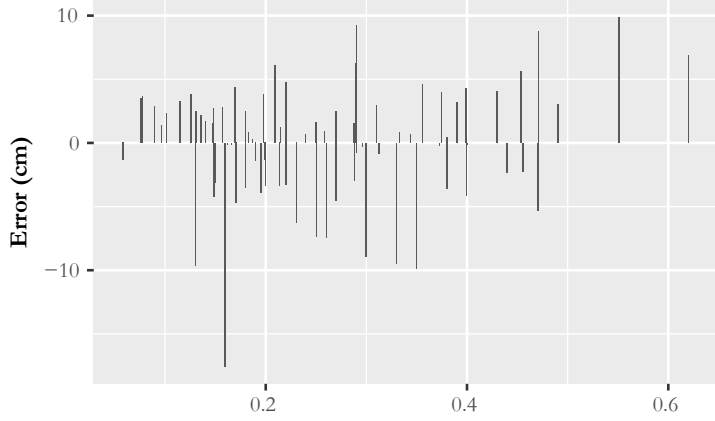

Otolith Weight (g)

C
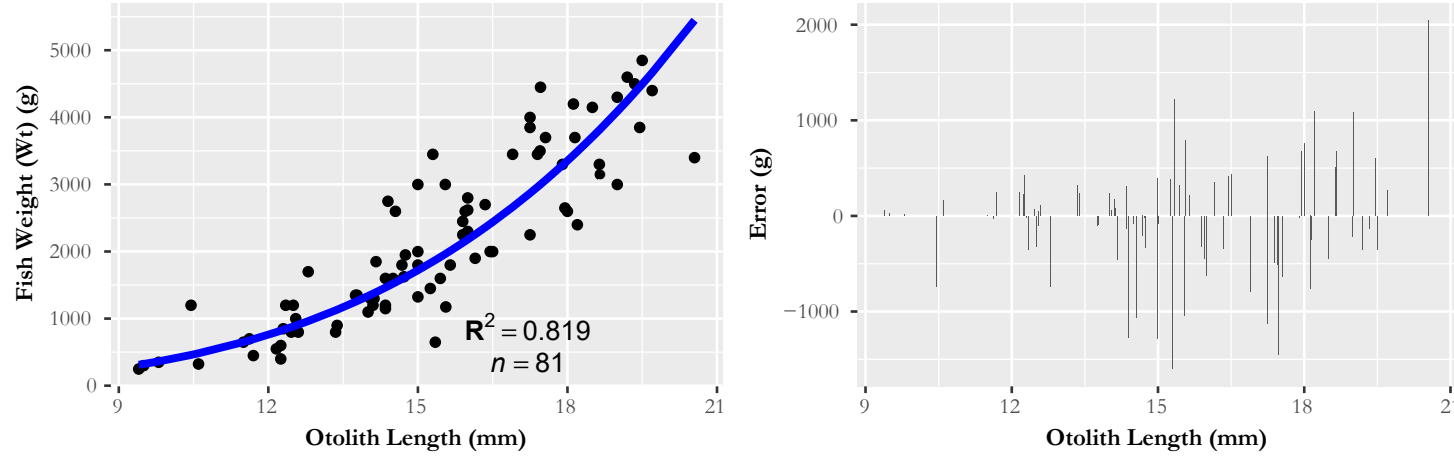

Otolith Length (mm)

D
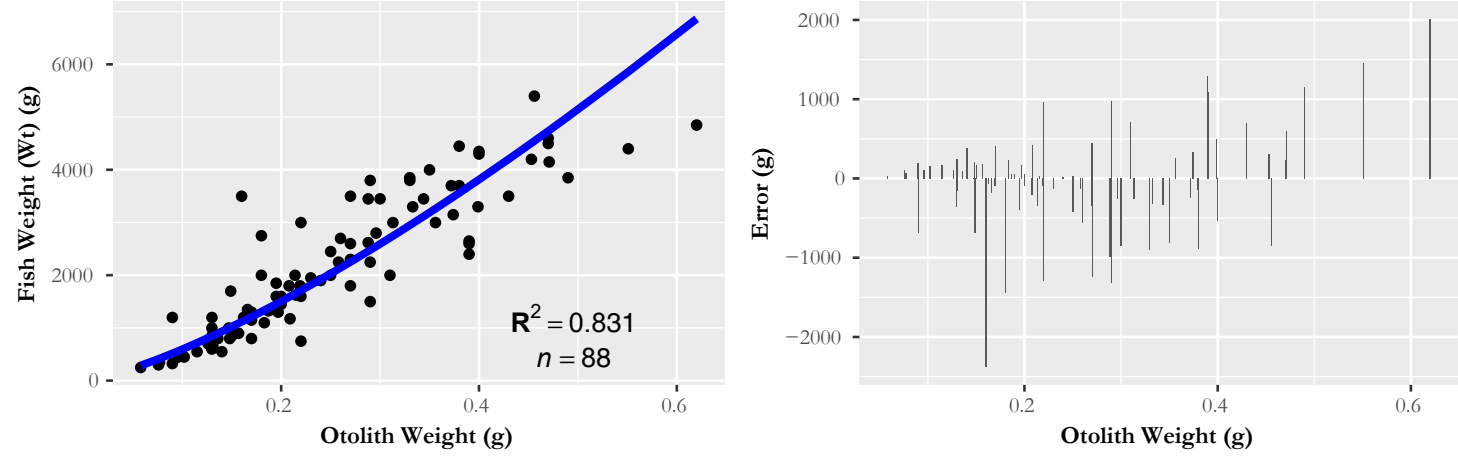

Figure 7. Power regressions between otolith length and weight data as explanatory variables for fish length and weight in the red grouper (Hyporthodus acanthistius) alongside with their respective residual plots. A) otolith length vs. fish length; B) otolith weight vs. fish length; C) otolith length vs. fish weight; and D) otolith weight vs. fish weight. 
Interestingly, we observed no sexual dimorphism for total fish length, total fish weight, or otolith external morphology in the Yellowtail snapper. In fact, lack of sexual dimorphism for fish length has previously been reported for Yellowtail snapper specimens of both sexes at all length classes recorded (Rojas et al., 2004b). Consequently, in the present study sex was not considered as an explanatory variable in any the fitted models.

The four fitted models relating Yellowtail snapper otolith length and/or weight with fish length and/or weight had low determination coefficients. We argue that the concavity of the otoliths by their distal surface made it difficult to measure their lengths along their surface, thus leading to measurement errors affecting the models based on otolith length. In the present study we took a straight measurement between the otolith's rostrum and its posterior side, likely introducing noise to the models tested. We believe it is important to devise a method for estimating the length of the otolith along its concave surface and to fit these data again to further evaluate model fitting. Although our best model (the power model) modestly fitted our Yellowtail snapper data, there is evidence that otolith length is a good predictor of fish length in other snapper species; Jawad et al., (2011) reported a robust relationship between otolith length and total length in a sample of 152 Bengal snappers (Lutjanus bengalensis) with a linear model $\left(\mathrm{R}^{2}=0.853\right)$.

As for the observed red grouper sagitta otoliths, these revealed features similar to those described in other serranid species, for instance, Dules auriga and Serranus atrobranchus from Brazil and Nemipterus japonicus (Nemipteridae; Seyfabadi et al., 2014); These parallels ought be regarded with caution, since serranid fishes are known to exhibit large interspecific variation in otolith morphology (Rossi-Wongtschowski et al., 2014). No otolith morphology descriptions or morphometric relationships were found for the species (Hyporthodus acanthistius) or the genus.

Tuset et al., (2005) reported for Serranus scriba that otolith length is the best predictor of fish length, while otolith weight is the best predictor of fish age, and because Nemipterus japonicus (Nemipteridae) showed a similar otolith morphology with that of our Red groupers ( $H$. acanthistius), we checked the different otolith morphology and body size relationships reported by Seyfabadi et al., (2014) Nemipterus japonicus in the northern Oman Sea $(n=150)$. The best fits were revealed by a linear model between otolith length and fish length (fork length), a power model between otolith length and fish weight, a power model between otolith weight and fish length, and a linear model between otolith weight and fish weight. In our study, the power model showed the best fit for all different relationships estimated: fish length (total length) as a function of otolith length, fish length as a function 
of otolith weight, total weight as a function of otolith length, and fish weight as a function otolith weight. Interestingly, all residual analyses done for all morphometric relationships in the two fish species subject of this study revealed better correlations between specimen size and otolith size when data points are in a middle of the magnitude range (i.e. medium fish and otolith sizes). Nevertheless, larger datasets are required for more robust estimations.

Transversal otolith sections in Red groupers showed structures clearly distinguishable as growth rings. Annual growth rings have been validated for similar tropical serranid fishes (Bullock et al., 1992; Craig et al., 1999; Manickchand-Heileman \& Phillip, 2000; Tuset et al., 2003; Tuset et al., 2005; Reñones et al., 2007), so annual growth rings are likely to occur in our Red groupers and so age and growth parameters could be estimated.

We applied a relatively simple method to describe otolith morphology from Yellowtail snapper and Red grouper specimens from the Colombian Pacific Ocean; however, we are aware of the availability of methods more suitable to analyze otolith features such as shape indices, providing species-diagnostic information (Tuset et al., 2003). Further development of this kind of investigations will help us overcome the difficulties posed by otolith size, for instance, using digital image processing systems and multivariate analyses (Lombarte \& Lleonart, 1993), and increasing the number of otoliths analyzed, will allow us to consider models based on the Huxley's allometric equation (Bervian et al., 2006) and geometric morphometric relations (Monteiro et al., 2005).

\section{Conclusions}

In this study, sagitta otolith morphologies were described for two economically important fish species in the Colombian Pacific Ocean. In this study relationships among otoliths length or weight with fish length or weight were significant for the Red grouper (H. acanthistius) but not for the Yellowtail snapper (L.argentiventris). Nonetheless, otolith morphology appeared to be useful for fish identification in the two species studied.

Transversal sections of all otoliths clearly revealed their internal structures and proved to be reliable for growth and age studies, however validation of the periodicity of growth rings is necessary. Furthermore, estimation of growth parameters via otolith inspection in these species will be useful to compare estimations already done with length frequency analysis. In Colombia, the study of these structures has the potential to improve our knowledge of fish life history and to be an important tool in fishery management. 


\section{Acknowledgements}

The authors acknowledge the National Natural Parks of Colombia and the Laboratory of Universidad del Cauca (Popayán, Colombia) for allowing us to take several pictures used in our analyses, Ms. Tatiana Meneses (AUNAP) for photo treatment, and Dr. Yasuji Masuda for his kind advice as well as the Fisheries Laboratory of Kagoshima University (Japan) for guiding us in the otolith sections. The authors are grateful to all fishermen who helped to collect the samples.

\section{Conflict of interests}

The authors declare having no conflict of interest.

\section{References}

Aiken KA. Aspects of reproduction, age and growth of the Lane Snapper, Lutjanus synagris (Linnaeus, 1758) in Jamaican coastal waters. In: Creswell RL (Ed), Procedures of the Gulf and Caribbean Fisheries Institute, 52: 116-134, 2001.

Arévalo JC, Gómez-Canchong P, Manjarres L. Análisis especial de los parámetros de crecimiento de Lutjanus synagris (Linnaeus, 1758) en el área norte del Caribe colombiano, a partir de la lectura de urohiales. In: Pesquerías demersales del área norte del Mar Caribe de Colombia y parámetros biológico - pesqueros y poblacionales del recurso pargo. Manjarres L (Ed.). Instituto Nacional de Pesca y Acuicultura INPA, Instituto Colombiano para el Desarrollo de la Ciencia y la Tecnología "Francisco José de Caldas" - COLCIENCIAS - 249-265, 2004.

Barreto CG, Borda CA. Evaluacion de Recursos Pesqueros Colombianos. Ministerio de Agricultura y Desarrollo Rural, Instituto Colombiano Agropecuario -ICA-, ISBN 978-9588214-69-6. 2008.

Auguié B. gridExtra: Miscellaneous Functions for "Grid" Graphics. $\mathrm{R}$ package version 2.3., 2017.

https://CRAN.R-project.org/package=gridExtra

Bervian G, Fontoura NF, Haimovici M. Statistical model of variable allometric growth: otolith growth in Microponias furnieri (Actinopterygii, Sicanidae), Journal of Fish Biology, 68: 196-208, 2006.

doi: $10.1111 / \mathrm{j} .1095-8649.2005 .00890 . x$ 
Bullock LH, Murphy MD, Godcharles MF, Mitchell ME. Age, growth and reproduction of jewfish Epinephelus itajara in the eastern Gulf of Mexico, Fishery Bulletin, 90(2): 243-249, 1992.

Campana SE. Photographic Atlas of Fish Otoliths of the Northwest Atlantic Ocean. NRC Research Press, Ottawa, Ontario. 284p.

Carvalho BM, Corrêa MFM. Morphometry of the sagitta otolith from Atherinella brasiliensis (Quoy and Gaimard, 1824) (Actinopterygii - Atherinopsidae), at the coast of Paraná, Rev. Trop. Oceanogr, 42 :54-59, 2014.

Claro R, Sierra-Sierra LM, García-Arteaga JP. Biología del Jocu, Lutjanus jocu (Bloch y Schneider, 1801) (Pisces: Lutjanidae) en las zonas NE y SW de la plataforma cubana, II. Alimentación, Edad y Crecimiento. Revista Investigaciones Marinas, 20(1-3): 30-38, 1999.

Colura RL, King TL. Using scales and otolith morphologies to separate spotted seatrout (Cynoscion nebulosus) collected from two areas within Galveston bay. In: Recent developments in fish otolith research. Secor, DH, Dean JM, Campana SE (Ed), University of South Carolina Press, 617-628, 1995.

Craig MT, Pondella DJ, Hafner JC. Analysis of age and growth in two eastern Pacific groupers (Serranidae: Epinephelinae), Bulletin of Marine Science, 65(3): 807-814, 1999.

Dowle M, Srinivasan A. Extension of 'data.frame'. R package version 1.11.0., 2018.

https:/ / CRAN.R-project.org/package=data.table

Farias I, Vieira AR, Serrano L, Figueiredo I. Otolith shape analysis as a tool for stock discrimination of the black scabbardfish, Aphanopus carbo Lowe, 1839 (Pisces: Trichiuridae), in Portuguese waters, Scientia Marina, 73 (S2): 47-53, 2009.

Friedland KD, Reddin DG. Use of otolith morphology in stock discriminations of Atlantic Salmon (Salmo salar), Canadian Journal of Fisheries and Aquatic Sciences, 51: 91-98, 1994.

doi: 10.1139/f94-011

Garcia ER, Potts JC, Rulifson RA, Manooch CS. Age and growth of yellowtail snapper, Ocyurus chrysurus, from the southeastern United States, Bulletin of Marine Science, 72(3): 909-92, 2003. 
Green BS, Mapstone BD, Arlos G, Begg GA. Tropical fish Otoliths: Information for Assessment, Management and Ecology (11 ${ }^{\text {th }}$ ed.). New York: Springer, 2009.

doi: 10.1007/978-1-4020-5775-5_9

Gjøsaeter J, Dayaratne P, Bergstad OA, Gjøsaeter H, Sousa MI, Beck IM. Ageing tropical fish by growth rings in the otoliths, FAO Fisheries Circular, 776: 01-54, 1984.

Jawad L, Al-Mamry J, Al-Busaidi H. Relationship between fish length and otolith length and width in the lutjanid fish, Lutjanus bengalensis (Lutjanidae) collected from Muscat City coast on the Sea of Oman, Journal of the Black Sea/Mediterranean Environment, $17(2): 116-126,2011$.

Lombarte A, Lleonart J. Otolith size changes related with body growth, habitat depth and temperature, Environmental Biology of Fishes, 37(3): 297-306, 1993.

doi: $10.1007 / \mathrm{BF} 00004637$

Manickchand-Heileman SC, Phillip DAT. Age and growth of the yellowedge grouper, Epinephelus flavolimatus, and the yellowmouth grouper, Mycteroperca interstitialis, off Trinidad and Tobago, Fishery Bulletin, 98(2): 290-298, 2000.

Martínez V, Monasterio de Gonzo G. Clave de identificación de algunos peces siluriformes en base al estudio de sus otolitos, Revista de la Asociación de Ciencias Naturales del Litoral, 22: 95-118, 1991.

Mejía Falla PA, Cortés E, Navia AF, Zapata FA. Age and Growth of the Round Stingray Urotrygon rogersi, a Particularly Fast-Growing and Short-Lived Elasmobranch, PLoS ONE, 9(4): e96077.

doi: 10.1371/journal.pone.0096077

Monteiro LR, Beneditto APM, Di Guillermo LH, Rivera LA. Allometric changes and shape differentiation of sagitta otoliths in sciaenid fishes, Fisheries Research, 74(1-3): 288-299, 2005.

doi: 10.1016/j.fishres.2005.03.002

Morales-Nin B. Growth determination of tropical marine fishes by means of otolith interpretation and length frequency analysis, Aquatic Living Resources, 2: 241-253, 1989.

doi: 10.1051/alr:1989029 
Morales-Nin B, Ralston S. Age and growth of Lutjanus kasmira (Forskål) in Hawaiian waters, Journal of Fish Biology, 36(2): 191203, 1990.

doi: 10.1111/j.1095-8649.1990.tb05595.x

Newman SJ. Growth rate, age determination, natural mortality and production potential of the scarlet seaperch, Lutjanus malabaricus Schneider 1801, off the Pilbara coast of north-western Australia, Fisheries Research, 58: 215-225, 2002.

doi: 10.1016/S0165-7836(01)00367-8

Newman SJ, Cappo M, Williams DMcB. Age, growth and mortality of the stripey, Lutjanus carponotatus (Richardson) and the brownstripe snapper, L. vitta (Quoy and Gaimard) from the central Great Barrier Reef, Australia, Fisheries Research, 48(3): 263-275, 2000 .

doi: 10.1016/S0165-7836(00)00184-3

Newman SJ, Williams DM, Russ GR. Age validation, growth and mortality rates of the tropical snappers (Pisces: Lutjanidae) Lutjanus adetii (Castelnau, 1873) and L. quinquelineatus (Bloch, 1790) from the central Great Barrier Reef, Australia, Marine and Freshwater Research, 47(4): 575-584, 1996.

doi: $10.1071 /$ MF9960575

Nolf D. Studies on fossil otoliths - the state of the art. In: Secor DH, Dean JM, Campana SE (Ed.). Recent developments in fish otolith research. The Belle W. Baruch Library in Marine Science, University of South Carolina Press: Columbia, USA, 1995.

Popper AN, Coombs S. The morphology and evolution of the ear in actinopterygian fishes, American Zoology, 22: 311-328, 1982.

Puentes V, Masuda Y, Matsuoka T. Age and growth of the yellowbelly threadfin bream Nemipterus bathybius in Kagoshima Bay, southern Japan, Fisheries Science (Fish. Sci.), 70 (3): 497-506, 2004.

doi: 10.1111/j.1444-2906.2004.00831.x

R Core Team. R: A language and environment for statistical computing. R Foundation for Statistical Computing, Vienna, Austria, 2018.

Retrieved from: http://www.R-project.org/ 
Reina MP, Ramírez H, Valderrama M. Edad y crecimiento de Paulicea luetkeni (Steindachner, 1876) (Pisces: Pimelodidae) en la lectura de estructuras duras (espinas de la aleta pectoral) en el alto río Meta (Colombia), Boletín cientifico INPA, 3: 115-130, 1995.

Reñones O, Piñeiro C, Masy X, Goñi R. Age and growth of the dusky grouper Epinephelus marginatus (Lowe 1834) in an exploited population of the western Mediterranean Sea, Journal of Fish Biology, 71 (2): 346-362, 2007.

doi: 10.1111/j.1095-8649.2007.01482.x

Robertson DR, Allen GR. Shorefishes of the tropical Eastern Pacific: An information system (Version 2.0), Smithsonian Tropical Research Institute, Balboa, Panama, 2006.

Rojas P, Zapata L. Peces demersales del Parque Nacional Natural Gorgona y su área de influencia, Pacífico colombiano, Biota Colombiana, 7 (2): 211-244, 2006.

Rojas P, Castillo B, Acevedo C, Gómez C, Loaiza J. Uso y Conservación del Recurso Peces: Parque Nacional Natural Gorgona - Área de influencia, Cali, Colombia: In: Garcés DM (Ed.) Sepia Ltda., 12, 2004a.

Rojas P, Gutiérrez C, Puentes V, Villa A, Rubio E. Aspectos de la biología y dinámica poblacional del pargo coliamarillo Lutjanus argentiventris en el Parque Nacional Natural Gorgona, Colombia, Investigaciones Marinas, 32 (2): 23-36, 2004b.

doi: $10.4067 /$ S0717-71782004000200003

Rossi-Wongtschowski CL, Correia Siliprandi C, Rito Brenha M, de Almeida Gonsales S, Santificetur C, Vaz-dos-Santos AM. Atlas of marine bony fish otoliths (Sagittae) of Southeastern - Southern Brazil Part I: Gadiformes (Macrouridae, Moridae, Bregmacerotidae, Phycidae and Merlucciidae); Part II: Perciformes (Carangidae, Sciaenidae, Scombridae and Serranidae), Brazilian Journal of Oceanography, 62 (special issue):1-103, 2014.

doi: 10.1590/S1679-875920140637062sp1

RStudio: RStudio Team. RStudio: Integrated Development for R. RStudio Inc., Boston, MA, 2016

http://www.rstudio.com/. Version 1.1.453.

Sadovy Y, Figuerola M, Roman A. Age and growth of red hind Epinephelus guttatus in Puerto Rico and St. Thomas, 'Fishery Bulletin', 90(3): 516-528, 1992. 
Sadighzadeh Z, Otero-Ferrer JL, Lombarte A, Fatemi MR, Tuset VM. An approach to unraveling the coexistence of snappers (Lutjanidae) using otolith morphology, Scientia Marina, 78(3): 353-362, 2014.

doi: $10.3989 /$ scimar.03982.16C

Seyfabadi J, Afshari M, Valinassab T. Otolith morphology and body size relationships of Nemipterus japonicus (Bloch, 1791) in the northern Oman Sea, Indian Journal of Fisheries, 61(2): 112-117, 2014.

Smale MJ, Watson G, Hecht T. Otolith Atlas of Southern African marine fishes. Ichthyological Monographs, J.L.B. Smith Institute of Ichthyology, 1: 1-232, 1995.

Soto-Rojas RL, Mejía-Arana F, Palacios JA, Hiramatsu K. Reproducción y crecimiento del pargo mancha Lutjanus guttatus (Pisces: Lutjanidae) en el Golfo de Nicoya, Costa Rica, Revista de Biologia Tropical, 57(1-2): 125-131, 2009.

doi: $10.15517 /$ rbt.v57i1-2.11303

Tuset VM, Lombarte A, González JA, Pertusa JF, Lorente MAJ. Comparative morphology of the sagittal otolith in Serranus spp., Journal of Fish Biology, 63(6): 1491-1504, 2003.

doi: 10.1111/j.1095-8649.2003.00262.x

Tuset VM, García-Díaz MM, González JA, Lorente MJ, Lozano IJ. Reproduction and growth of the painted comber Serranus scriba (Serranidae) of the Marine Reserve of Lanzarote Island (CentralEastern Atlantic). Estuarine, Coastal and Shelf Science, 64 (2-3): 335-346, 2005.

doi: $10.1016 /$ j.ecss.2005.02.026

Tuset VM, Lombarte A, Assis CA. Otolith atlas for the western Mediterranean, north and central eastern Atlantic, Scientia Marina, 72(S1): 7-198, 2008.

doi: $10.3989 /$ scimar.2008.72s 17

Williams T, McEldowney A. A guide to the fish otoliths from waters off the Australian Antarctic Territory, Heard and Macquarie Islands, ANARE Research Notes, 75: 1-173, 1990.

Wickham H. ggplot2: Elegant Graphics for Data Analysis. SpringerVerlag New York, Version 2.2.1., 2016. 
Yamauchi M, Tanaka J, Hanada Y. Comparative study on the morphology and the composition of the otoliths in the teleosts, Acta Oto-laryngologica, 128(8): 846-55, 2008.

doi: 10.1080/00016480701775005

Zapata FA, Herrón PA. Pelagic larval duration and geographic distribution of tropical eastern Pacific snappers (Pisces: Lutjanidae), Marine Ecology Progress Series, 230: 295-300, 2002.

doi: $10.3354 /$ meps 230295

\section{Morfología y relaciones morfométricas para los otolitos sagitta en Lutjanus argentiventris (Pisces: Lutjanidae) y Hyporthodus acanthistius (Pisces: Serranidae) del Océano Pacífico colombiano}

Resumen: Las formaciones pétreas del oído de los peces, u otolitos, son estructuras auriculares internas que se pueden estudiar para determinar la edad de los peces y son una fuente de datos informativos taxonómicamente. En el presente trabajo se colectaron otolitos sagitta del pargo amarillo (Lutjanus argentiventris) y del mero rojo (Hyporthodus acanthistius) en el Pacífico colombiano, y se estudiaron sus características morfológicas claves. Los otolitos del pargo amarillo fueron distintivamente cóncavos por su superficie distal, con lo cual revelaron características compartidas con especies de su género (Lutjanus). Los otolitos del mero rojo eran elípticos y comprimidos lateralmente por su superficie proximal, lo cual los hace similares a los de otras especies de serránidos. Se estudiaron también las relaciones morfométricas entre el tamaño y peso de los otolitos y el tamaño y peso del pez completo. En el mero rojo se encontraron relaciones morfométricas estadísticamente significativas, a través de modelos potenciales de regresión, entre los otolitos y las características corporales. Se relacionó la longitud del otolito con la longitud total del pez, el peso del otolito con la longitud total del pez, la longitud del otolito con el peso total del pez y el peso del otolito con el peso total del pez. No se encontraron relaciones morfométricamente significativas para los datos del pargo amarillo. En ambas especies de peces las secciones transversales del otolito probaron ser mejores para identificar sus características internas y distinguir sus anillos de crecimiento, como método para determinar la edad del espécimen.

Palabras clave: Océano Pacífico colombiano; Hyporthodus acanthistius; Lutjanus argentiventris; otolitos. 


\section{Morfologia e relaçóes morfométricas para os otólitos sagita em Lutjanus argentiventris (Pisces: Lutjanidae) e Hyporthodus acanthistius (Pisces: Serranidae) do Oceano Pacífico colombiano}

Resumo: As concreções de carbonato de cálcio do ouvido dos peixes, ou otólitos, são estruturas auriculares internas que podem ser estudadas para determinar a idade dos peixes e são uma fonte de dados taxonômicos. No presente trabalho se coletaram otólitos sagita de pargo amarelo (Lutjanus argentiventris) e de mero vermelho (Hyporthodus acanthistius) no pacífico colombiano, e se estudaram suas características morfológicas principais. Os otólitos de pargo amarelo foram distintivamente côncavos na sua superfície distal, pelo que revelaram características compartidas com outras espécies do seu gênero (Lutjanus). Os otólitos de mero vermelho eram elípticos e comprimidos lateralmente pela sua superfície proximal, o qual os fazem similares aos de outras espécies de serránidos. Foram estudadas também as relações morfométricas entre o tamanho e peso dos otólitose o tamanho e peso do peixe completo. No mero vermelho se observaram relações morfométricas estatisticamente significativas, através de modelos potenciais de regressão, entre os otólitos e as características corporais. Relacionou-se o comprimento do otólito com o comprimento total do peixe, o peso do otólito com o comprimento total do peixe, o comprimento do otólito com o peso total do peixe e o peso do otólito com o peso total do peixe. Não foram encontradas relações morfométricamente significativas para os dados do pargo amarelo. Em ambas espécies de peixe as seções transversais do otólito provaram ser melhores para identificar suas características internas e distinguir seus anéis de crescimento, como método para determinar a idade do espécime.

Palabras clave: Oceano Pacífico colombiano; Hyporthodus acanthistius; Lutjanus argentiventris; otólitos. 


\section{Vladimir Puentes Granada, PhD}

25 years' experience in marine biology, environmental and fisheries management as lecturer and advisor for governmental and private institutions. Degree at Valle University (Cali, Colombia), MSc and $\mathrm{PhD}$ degree at Kagoshima University (Japan). Work experience with Universities, Fisheries Authority, National Natural Parks, Ministry of Environment, NGOs, environmental impact assessment and deep-sea knowledge generation in the offshore industry, and both environmental and fisheries international conventions.

\section{Paola Rojas}

Marine Biologist (Valle University, Colombia) and specialist in applied statistics (Valle University, Colombia). Extensive experience leading research and conservation projects on fisheries and fisheries management in protected areas and their influence zones of the Colombian Pacific. Work experience as independent consultant, National Natural Parks and national and international NGOs in Colombia.

\section{Giovanni Pavolini BEng (c)}

Mechanical Engineer (Valle University, Colombia) with postgraduate studies in optimization (Yokohama National University, Japan). Working experience in data processing, statistics analysis, and optimization in different industries and environments as Senior consultant.

\section{Carlos F. Gutierrez, PhD (c)}

Marine Biologist with experience in both marine and plant physiological research. Professional degree at Valle University with 20 years' experience. Work experience with National Natural Parks, especially in Gorgona Island, sanitary engineering and several private initiatives. Currently $\mathrm{PhD}$ candidate working on physiological response of macrophyte plants. 


\section{Angel A. Villa}

20 years' experience in marine biology and fisheries. Professional degree at Valle University. Work experience with both private and governmental agencies in UPRA, AUNAP, National Natural Parks, Pacific Research Institution -IIAP- and regional environmental authority -CVC-, Universities (Valle Univ., Technological Chocó Univ.), NGOs, and as representative of the small scale fisheries sector in the Federación de Trabajadores de la Pesca Artesanal (Colombia). 